Vol. 10(8), pp. 858-864, 19 February, 2015

DOI: 10.5897/AJ AR2013.7312

Artic le Number: B69E96E50681

ISSN 1991-637X

Copyright (c) 2015

African Journal of Agricultural

Author(s) retain the copyright of this artic le

Research

http://www.academicjoumals.org/AJAR

\title{
Review of patents on life cycle assessment
}

\author{
Lidiana Zocche ${ }^{1 *}$, Luan Carlos Santos Silva ${ }^{1}$, Cassiano Moro Piekarski ${ }^{2}$ and \\ Antonio Carlos de Francisco ${ }^{2}$
}

\footnotetext{
${ }^{1}$ Department of Production Engineering, Federal University of Rio Grande do Sul (UFRGS), Porto Alegre-RS, Brazil. ${ }^{2}$ Department of Production Engineering, Federal University of Technology - Paraná (UTFPR), Ponta Grossa-PR, Brazil.
}

Received 30 April, 2013; Accepted 22 January, 2015

\begin{abstract}
Many tools are developed and used in order to evaluate the environmental impacts in products and services. One tool that is gaining prominence is the Life Cycle Assessment (LCA), which can analyze environmental aspects and impacts along the life cycle of product. However, not much is known about the patent generation through the use of LCA. In this sense, this paper aims to investigate LCA studies that generated patents through innovation in both products and processes. To reach the proposed objective, three patents basis data were used: WIPO, INPI and EPO. Eleven different patents requested involving LCA applications were found. The LCA and innovation generation need to be more explored, expanding the vision of organizations for this issue. LCA has a great potential to improve the environmental performance of products, processes and services and, at the same time, can assist in innovations generation and in technological development through patents requests.
\end{abstract}

Key words: Life Cycle Assessment (LCA), innovation, patents.

\section{INTRODUCTION}

Environmentally correct studies about the environmental performance are in evidence through awareness campaigns, and show that companies are increasingly treating and valuing environmental information combined with the life cycle of products to meet the demand of market consumers of products.

Thus, the life cycle of products has evolved in a context where demands for health and environmental requirements are raised by various stakeholders such as authorities, companies and social organizations, increasing demands for environmentally oriented products and targeting innovations through technological changes with the lowest possible environmental impact (Tidd et al., 2005; Azapagic, 1999).

In this context, several methods are being developed to assess the environmental impacts in the life cycle of products, processes or activities for the purpose of regulation and support in business decisions. One method that is gaining prominence is the Life Cycle Assessment (LCA) which has been used as a management tool in an integrated, systematic and multidisciplinary way, quantifying environmental loads and their potential impacts along the life cycle of a product, process or activity (Pieragostini et al., 2012; 


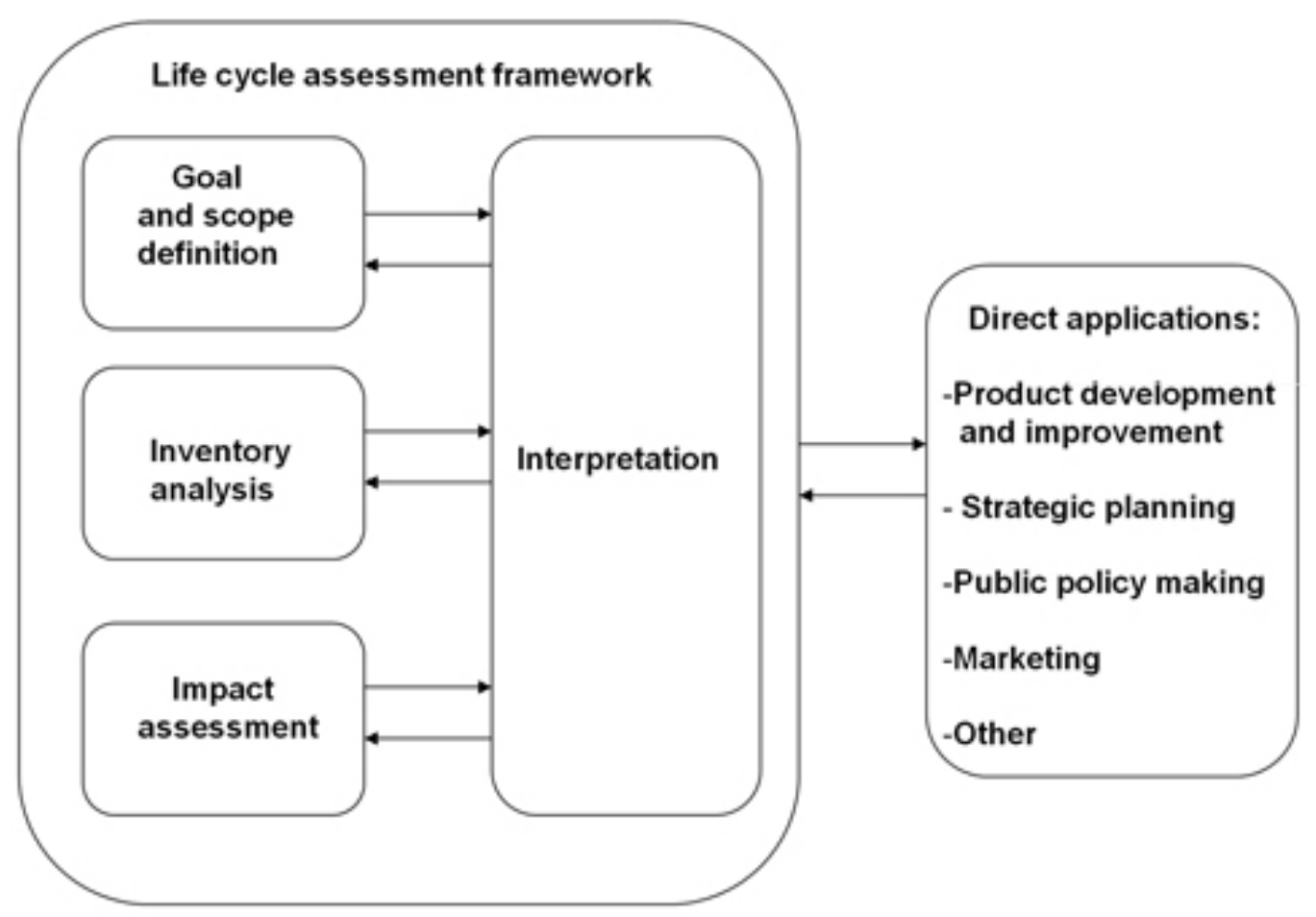

Figure 1. Phases of life cycle assessment. Source: Database of the ISO (2006a).

Wonglimpiyarat, 2005).

This indication resulting from LCA and the search for improvements in the production process enables that at the same time that companies seek to improve the environmental performance of its products this can result in technological innovations for the industry. Many authors complement their studies saying that LCA is a crucial tool for companies wishing to reach results of excellence and to facilitate green innovations.

Therefore, according to Oliveira et al. (2010), these new technologies can be identified through the analysis of patent applications in some fields.

In this context, the aim of this article was to conduct a survey of LCA studies that generated patents through innovation in both products and processes.

\section{LIFE CYCLE ASSESSMENT (LCA)}

LCA is a technical tool of analytical approach and managerial character which contributes to the evaluation of the environmental aspects and potential impacts associated with a product or activity during its life cycle (Garraín et al., 2010; Lofgre et al., 2011; Chauhan et al., 2011; Abdallah et al., 2012).

In general terms according to Lofgren et al. (2011), the aim in relation to the use of LCA is to satisfy customers orders and simultaneously achieve an ideal balance between the product and the environment. The methodology (LCA) has developed and matured over the last decades. Current activities about databases, quality assurance, consistency and harmonization of methods contributed to this.

The LCA methodology is internationally structured and standardized by the International Organization for Standardization (ISO), belonging to the series ISO 14040 and 14044 (ISO 2006a, b). Both are considered the main and most important standards for environmental assessment based on the life cycle of product.

The methodology consists of four phases: aim definition and scope, inventory analysis, impact assessment and interpretation. The iteration between these phases can be observed in Figure 1.

The first phase of the LCA comprises the definition of the objective and scope. The goal of an LCA study should unequivocally declare the intended application, the reasons for conducting the study and target audience ISO 14040 (2009a). The scope includes the cover of the study. According to Sherwani et al. (2010), Pieragostini et al. (2012), Zhou et al. (2011) and Roy et al. (2009), the system boundaries, the functional unit and the system limits should be stated clearly in the scope of the product system to be studied.

The analysis of the inventory, the second stage of LCA, involves an extensive database of materials involved in the product or system including the surveying, the collecting and analyzing data required for LCA (Jijakli, 2012; Olsen et al., 2001; Guinée et al., 2011). 
The phase of impact assessment consists in studying the significance of environmental impacts from the inventory data. At the end of the impact assessment of the life cycle, the final result is an environmental profile of the product system under study, as defined in the aim and scope. These results are interpreted in the last phase of the methodological framework of life cycle assessment (Benetto and Klemes, 2009).

The last stage of evaluating the structure of the life cycle, comprises the interpretation. In this phase, the information from the inventory analysis and impact assessment system is evaluated, and conclusions in accordance with the objectives outlined in the first phase of the study are proposed (Benetto and Klemes, 2009; Jijakli, 2012; ISO 1440, 2009).

The authors Garraín et al. (2010), Lofgre et al. (2011) and Chauhan et al. (2011) add that life cycle analysis is a technical tool with analytical approach and managerial character, which contributes to the evaluation of the environmental aspects and potential impacts, associated with a product or activity during its life cycle, through the obtained data.

\section{Life cycle assessment (LCA) as a tool for generating innovation}

Nowadays, there is a strong pressure to innovate around the world. The innovation has been regarded by researchers as a strategic issue, a key for business success in an increasingly competitive environment as a result of intense technological development and the expectation of new products by consumers. This leads the companies to the need for constantly innovate.

According to Cramer and Tukker (2006), environmental demands are largely focused on innovation through adaptation of processes, products and services due to the regulations, considering that the best results are expected in relation to environmental aspects, at lower costs, thereby extending the range of answers to all stages of the life cycle.

For the process of technological innovation in organizations which results in sustainable products and processes, Figueirêdo et al. (2010) emphasizes that the availability and use of methodological tools which facilitate the consideration of environmental issues in every stage of this process is necessary.

In parallel with this, many methods are being developed to assess the environmental impacts of products for regulation and support in business decisions about the product improvement generating innovations (Krozer, 2008; Guziana, 2011). In this sense, one tool that is gaining prominence is the Life Cycle Assessment (LCA), which can provide fundamental technological shifts in production and in life cycle of products and services.

The LCA allows obtaining knowledge of the life cycle of the product as a whole, covering all stages of the product development process, including inputs and outputs in each process step. This makes possible to identify the unfavorable points of the product related to environmental aspects. Thus, the search for alternatives to improve the environmental performance of this product may result in innovations to the industry (ISO, 2009a; Lofgren et al., 2011).

According to Demuner et al. (2011) and Moen and Jorgensen (2010), the competitiveness of a company is related to its ability to research and implement innovative opportunities. Chiou et al. (2011), Tseng (2010) and Yung et al. (2011) reinforce that LCA is, in general, an innovative tool for industries.

The operationalization of the production system allied the innovations, which aim to meet the dimensions of sustainability and are considered imminent trends for organizations that want to remain competitive and consolidate good results. On this aspect, Luz (2011) states in his study, which evaluates the contribution of indicators obtained from the analysis of the life cycle on the generation of innovation in the industry, that the use of LCA may result in innovations and consequently improving competitiveness.

Corroborating with this thought, Kemp et al. (1999), Chiou et al. (2011), Tseng (2010) and Yung et al. (2011) emphasize that LCA is presented as a tool for assessing the environmental impact, able to recognize the multifaceted nature of environmental innovation; promoting improvements composed by the product innovation, process innovation and innovation in services. With the purposes of reducing the negative impacts and risks to the environment.

In this aspect, Madival et al. (2009), Rousset et al. (2011), Rodríguez et al. (2011), Li et al. (2010) and Abdallah et al. (2012) highlight the concerning of the LCA application in industry in which it is possible to observe the generation of technological changes both in product, process and service. These innovations may result in patents through the use of this methodology.

\section{Study of patents related to LCA}

A patent is an exclusive right granted for an invention, which is a product or a process that provides, in general, a new way of doing something, or offers a new technical solution to a problem (WIPO, 2013).

The patents provide incentives to individuals by offering them recognition for their creativity and material reward for their marketable inventions. These incentives encourage innovation, which assures that the quality of human life is continuously enhanced.

According to the World Intellectual Property Organization (WIPO), the number of patent applications has grown around 1.5 million each year, resulting in more than 500.000 patents granted. Companies in the United 
States, Japan and Europe are increasingly using this instrument as strategic input.

\section{METHODOLOGY}

In order to verify if LCA studies generate patents through its innovations, a research at the patents basis "WIPO" - Word Intellectual Property Organization was carried out. The option to use the WIPO was due to the fact that it is a broad tool of patents research, whose mission is to promote innovation and creativity for economic, social and cultural development of all countries through a balanced and effective intellectual (patents, copyrights, trademarks, designs, etc.) international property. Searches were also conducted at INPI - National Institute of Industrial Property (INPI), which is responsible for the improvement, dissemination and management of the Brazilian system of granting and guarantee of intellectual property rights for industry and EPO - European Patents Office, which contains all information publicly available on European patent applications. The study was conducted in March 2013 and the keyword searched was "life cycle assessment (LCA)."

This analysis involved the acquisition of information, such as the nationality of the applicant, the nature of the application, the priority date and associated international patent classifications, as well as the title of technology. This research aimed to map the information protected in Brazil and consequently analyzing its importance on a global scale.

\section{RESULTS AND DISCUSSION}

Among the three basis of patents surveyed only at the base, WIPO eleven patent requests related to the topic ACV were found.

The first patent request occurred in 2001 in Japan, with the title: "Method for using a feature analysis of twodimensional energy sources expressed by an influence of the life cycle of the environment and life cycle and costs of a system", whose aim was to provide information about the influences of energy sources in an environment, through analyzing the influence of environmental life cycle costs and life cycle through the LCA.

In the following year, Japan entered with two new patent requests: "Evaluation system of environmental effects of products and services"; a system that is able to objectively evaluate the recycling which is susceptible to subjectivity in an LCA, and to show quantitatively the total environmental load from products and services. The other patent application, "Process Evaluation System", aims to calculate and assess the value of environmental load of the production process based on the content of the production process and Life Cycle Assessment LCA, through CAD and CAM system. The application was required by Fuji Electric Co Ltd. The same company has filled its second patent application in 2005, "Life Cycle Evaluation System"; this system aims to quickly modify the design in order to make the life cycle longer through the CAD system and LCA.

Later in 2005, Japan held two more patent applications: "Water in oil, aerosol type product", in order to provide an emulsion that is preferable from the point of view of life cycle assessment (LCA), required by the company Daizo: KK and "System and Method for Evaluation of the Life Cycle" which allows provision of an LCA system capable of simultaneously evaluating the environmental impact of the life cycle of the product and energy consumption of the facilities, referring to the company Hitachi Ltd.

The Republic of Korea requested this year, its first patent application: "Method for assessment of the integration for eco-design of an automobile through an integrated index, including recycling". This method evaluates the recycling (via LCA data and disassembly) of the automobile, and analyzes a weak point in order to increase the recycling of a design step from a concept of concurrent engineering, as the Hyundai Motor Company conducted the application.

In 2007, the company Nippon Oil Corp., installed in Japan, held the patent application: "Method for production of hydrogen to produce reformed gasoline and for production of aromatic hydrocarbons" aiming to provide a method to produce hydrogen, sufficiently effective to reduce $\mathrm{LCA} \mathrm{CO}$.

In 2009, the company Hitachi Ltd., made its second patent application: "System support to the project", in which an environmental assessment and system design support are provided and a database is obtained by the Association of Product Classification Information, in order to solve some problems of LCA methodology.

In 2010, the first patent application was required via PCT (Cooperation Treaty Patent) comprising a multilateral treaty which allows requirement of patent protection for an invention simultaneously in many countries through the filling of a single international patent application. In this sense, the patent entitled "System support for the project through sustainable project" aims to create an environment of social participation based on integrated software with the design of sustainable products and tools from LCA and processes.

In 2012, the Republic of Korea held its second patent application, by the Research Foundation and Business Sungkyunkwan University, called: "Method for the use of a feature of two-dimensional energy sources analysis expressed by an influence of the environment life cycle and the costs of a system life cycle", capable of providing information about the influences of energy sources in an environment, analyzing the influence through the environmental life cycle and life cycle costs through the LCA.

Table 1 illustrates the information described above, relating the year, the patent classification, the applicant company and the country.

According to the INPI - National Institute for Intellectual Property, the patents have different classifications. Hereafter the classification of patent applications found are described:

- The class G06F covers equipment or methods of digital 
Table 1. Relationship title, purpose, classification, applicant and the year of filing. Source: Own Authors (2013).

\begin{tabular}{|c|c|c|c|c|}
\hline Title & Purpose & Classification & Applicant / Inventor & Year \\
\hline $\begin{array}{l}\text { Method and device for evaluating environmental influence by } \\
\text { evaluating the life cycle. }\end{array}$ & $\begin{array}{l}\text { Evaluate the loads through databases with one of its key elements an } \\
\text { inventory to calculate and evaluate the consumption of resources and } \\
\text { energy. }\end{array}$ & G06F & $\begin{array}{l}\text { National Institute of Advanced Industrial } \\
\text { Science and Technology, Ministry of } \\
\text { Economy, Trade and Industry (METI) }\end{array}$ & 2001 \\
\hline $\begin{array}{l}\text { Evaluation system of environmental effects of products and } \\
\text { services. }\end{array}$ & $\begin{array}{l}\text { Objectively evaluate recycling in an LCA and quantitatively show the total } \\
\text { environmental load of products and services. }\end{array}$ & G06Q & Kankyo Technos KK & 2002 \\
\hline Evaluation system of processes. & $\begin{array}{l}\text { Calculate and evaluate the environmental load value of manufacturing } \\
\text { process based on LCA through CAD and CAM. }\end{array}$ & G05B & Fuji Electric Co Ltd. & 2002 \\
\hline Life cycle evaluation system. & Fast modification project by LCA & G06F & Fuji Electric Co Ltd. & 2005 \\
\hline Water in oil, aerosol product. & Develop a sustainable product from the point of view of ACV. & B65D & Daizo: KK. & 2005 \\
\hline System and Life Cycle Assessment method. & LCA applied to the product and the energy consumption of facilities. & G05B & Hitachi Ltd. & 2005 \\
\hline $\begin{array}{l}\text { Evaluation method of integration for the eco-design of an } \\
\text { automobile by an integrated index including recycling. }\end{array}$ & $\begin{array}{l}\text { The objective is to evaluate the car recycling through LCA data and } \\
\text { disassemblying. }\end{array}$ & G05F & Hyundai Motor Company & 2005 \\
\hline $\begin{array}{l}\text { Hydrogen production method for producing reformed gasoline } \\
\text { and producing aromatic hydrocarbons. }\end{array}$ & $\begin{array}{l}\text { This new method allows to innovate the hydrogen production process, } \\
\text { effective enough to reduce the environmental impacts by evaluating the } \\
\text { life cycle (LCA). }\end{array}$ & CO1B & Nippon Oil Corp & 2007 \\
\hline Support system for the project. & $\begin{array}{l}\text { An environmental assessment through LCA and design support system } \\
\text { are provided in which a database is obtained by associating the product } \\
\text { rating information. }\end{array}$ & G06F & Hitachi Ltd. & 2009 \\
\hline Support system for the project through sustainable design. & $\begin{array}{l}\text { Create an environment of social participation based on an integrated } \\
\text { software to design sustainable products, LCA tools and processes. }\end{array}$ & G06F & Sustainable Minds llc & 2010 \\
\hline $\begin{array}{l}\text { A method for analyzing the use of energy sources two- } \\
\text { dimensionally expressed by an influence of the environment life } \\
\text { cycle and the life cycle costs of a system }\end{array}$ & $\begin{array}{l}\text { Provide information on the influence of energy sources in an } \\
\text { environment, analyzing the influence by environmental life cycle and the } \\
\text { life cycle costs through LCA. }\end{array}$ & G06Q & $\begin{array}{l}\text { Research and Business Foundation, } \\
\text { Sungkyunkwan University }\end{array}$ & 2012 \\
\hline $\begin{array}{l}\text { Method and system to assess the environmental impact of a } \\
\text { processing device. }\end{array}$ & $\begin{array}{l}\text { Develop a method and system for evaluating the environmental impact of } \\
\text { process equipment item via ACV. }\end{array}$ & G06G & Ebner Fritz F & 2013 \\
\hline Data Management for Life Cycle Assessment (LCA). & $\begin{array}{l}\text { Provide inventory data life cycle (ICV) via a secure structure for a data } \\
\text { center. }\end{array}$ & G06F & Huizenga Neil Gregory & 2013 \\
\hline
\end{tabular}

computing or data processing, specially adapted for specific applications;

- The class G06Q comprises systems or data processing methods, specially adapted for administrative, commercial, financial, management, supervision or prediction purposes; systems or methods specially adapted for administrative, commercial, financial, management, supervision or prediction purposes, not otherwise provided for;

- The class G05B comprises the control and regulation. This class includes methods, systems, and devices for control in general;

- The class C01B includes nonmetallic elements and their compounds;

- The class B65D covers containers for storage or transport of articles or materials.

Japan stands out among the patent applications analyzed in this study, due to the rate of technological development and research of the country. Thus, Japan has demonstrated its concern for sustainability, seeking innovation through ways that enable and feature the minimization of environmental impacts caused by developed products, processes and services. Moreover, Demuner et al. (2011) justifies a strong interest of Japanese companies to invest and 


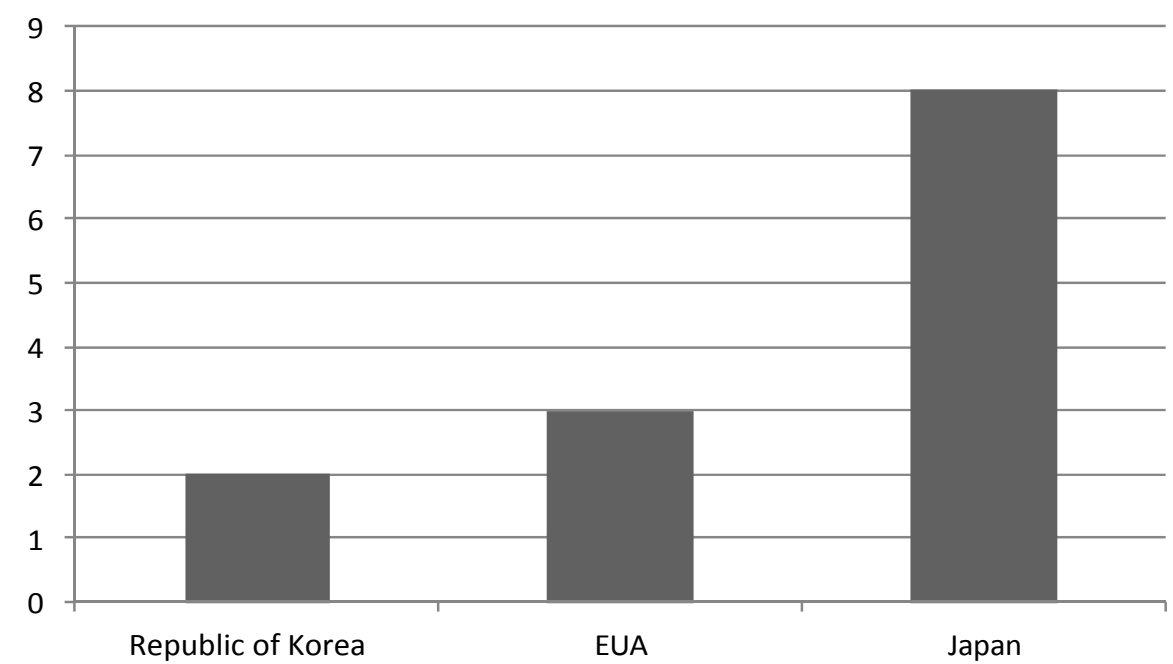

Figure 2. Value of countries and number of patent applications. Source: Database of the WIPO (2013).

develop its own technology. Sánchez et al. (2011) provided evidence that the best performing companies have an innovative behavior. Following Japan is the United States of America especially by applying for a patent via PCT and lastly is the Republic of Korea.

Among the pending applications for patents, only one is linked to a university. The industries represent the remainder of patent applications belonging to different sectors: automotive, electronics, energy, software, petrochemicals, gas and coal. These industries seek the commitment to innovation and environmental sustainability.

Figure 2 illustrates the relationship of the countries with the number of patent applications, highlighting the patents ratings required by Japan. As highlighted in Figure 2, the largest number of patent applications is represented in Japan whose focus is information technology applications related to software integrated with the design of sustainable products through LCA tools and systems support projects.

The Graph 1 illustrates the amount of patent applications between 2001 and 2013. You can see that the first application for patent related LCA occurred in 2001 , with a significant increase by the year 2005, which had the highest number of patent applications. This year there was a decline in the requests, returning to growth only in 2013.

\section{Conclusions}

This article was developed with the intention of checking LCA studies which enabled the generation of innovations through patents generated by the application of this methodology.

It was noticed that the LCA has great potential to assist in the generation of innovation and patents, but this issue needs to be explored further, expanding the vision of organizations for that matter, since, in a study of LCA, there are generated indicators that enable a vision system as a whole; generating information which can be used to guide the actions and decisions of the companies. To enable us evaluate the implementation of generation of innovation in order to promote significant improvements aiming to enhance or reduce its impact in the environment and still be useful for the strategic planning of the company allowing the identification of innovation opportunities that had not yet been exploited.

Therefore, companies should incorporate monitoring systems and signs of change through LCA studies. Where, at the same time as they seek to produce in sustainable way, companies can use the LCA strategically and become more competitive and innovative in the market.

\section{Conflict of Interest}

The authors have not declared any conflict of interest.

\section{REFERENCES}

Abdallah T, Farhat A, Diabat A, Kenned S (2012). Green supply chains with carbon trading and environmental sourcing: Formulation and life cycle assessment. Appl. Math. Model. 36(9):4271-4285.

Azapagic A (1999). Life cycle assessment and its application to process selection, design and optimization. Chem. Eng. J. 73(1):1-2.

Benetto E, Becker M, Welfring J (2009). Life Cycle Assessment of Oriented Strand Boards (OSB): from Process Innovation to Ecodesign. Environ. Sci. Technol. 43(15):6003-6009.

Chauhan MK, Chaudhary VS, Kumar SS (2011). Life cycle assessment of sugar industry: A review. Renew Sust. Energy Rev. 15(7):34453453.

Chiou TY, Chan HK., Lettice F, Chung SH (2011). The influence of greening the suppliers and green innovation on environmental 
performance and competitive advantage in Taiwan. Transportation Transport. Res. E-Log. 47(6):822-836.

Cramer JM, Tukker A (2006). Product innovation and eco-efficiency in theory. Product innovation and eco-efficiency. Dordrecht/Boston/London: Kluwer Academic Publishers pp. 3-30.

Demuner BJ, Junior NP, Delaide MS, Antunes AMS (2011). Technology Prospecting on Enzymes for the Pulp and Paper Industry. J. Technol. Manage. Innov. 6(1):148-158.

Figueirêdo MCB, Rodrigues GS, Pires AC, Rosa MF, Mota FSB (2010). Métodos de avaliação do desempenho ambiental de inovações tecnológicas agroindustriais. Rev. Espacios 31:4.

Garraín D, Vidal R., Martínez P, Muñoz C (2010). Análisis del Ciclo de Vida de los Procesos de Recubrimiento Metálico de Termoplásticos. Inform. Tecnol. 2(2):59-64.

Guinée JB, Reinout $H$, Gjalt $H$, Zamagni A, Masoni P, Buonamici R, Ekvall T, Rydberg T (2011). Life Cycle Assessment: Past, Present, and Future. Environ. Sci. Technol. 45(1):90-96.

Guziana B (2011). Is the Swedish environmental technology sector 'green'? J. Cle. Pro. 19(18):827- 835.

ISO (2006a). ISO Norm 14040:2006, Life cycle assessment: Principles and framework. Environmental management (ISO).

ISO (2006b). ISO Norm 14044:2006, Life cycle assessment: Requirement and guidelines. Environmental management (ISO).

Jijakli K, Arafat H, Kennedy S, Mande P (2012). How green solar desalination really is? Environmental assessment using life-cycle analysis (LCA) approach. Desalination 287(15):123-131.

Kemp R, Smith K, Becher G (1999). How should we study the relationship between environmental regulations and innovation? Final report. Seville.

Krozer Y (2008). Life cycle costing for innovations in product chains. J. Cle. Pro. 16(3): 310-32.

Li X, Zhu Y, Zhang Z (2010). An LCA-based environmental impact assessment model for construction processes. Build. Environ. 45(3): 766-775.

Lofgren B, Tillman A, Rinde B (2011). Manufacturing actor's LCA. J. Cle. Pro. 19(17-18):2025-2033.

Luz LM (2011). Proposta de modelo para avaliar a contribuição dos indicadores obtidos na análise do ciclo de vida sobre a geração de inovação na indústria. 2011. 165 f. Dissertação (Mestrado em Engenharia de Produção) - Programa de Pós-Graduação em Engenharia de Produção, Universidade Tecnológica Federal do Paraná. Ponta Grossa.

Madival S, Auras R, Singh SP, Narayan R (2009). Assessment of the environmental profile of PLA, PET and PS clamshell containers using LCA methodology. J. Cle. Pro. 17(13):1183-1194.

Moen O, Jorgensen RB (2010). The New Managerial Challenge: Transforming Environmental and Health Issues to Competitive Advantages. J. Technol. Manage. Innov. 5(2):24-36.

Oliveira LG, Carestiato T, Mothé CG, Souza RV (2010). Technological Monitoring Study Based on Invention Patents of Omeprazole and Derivatives with Pharmaceutical Applications. J. Technol. Manage. Innov. 5(3):111-119.
Olsen SI, Christensen FM, Hauschild M, Pedersen F, Larsen HF, Torslov J (2001). Life cycle impact assessment and risk assessment of chemicals - a methodological comparison. Environ. Impact Asses. 21(4):385-404.

Pieragostini C, Mussati MC, Aguirre P (2012). On process optimization considering LCA methodology. J. Environ. Manage. 96(1):43-54.

Rodríguez RMA, Ruyck J, Díaz RP, Verma CK, Bram S (2011). An LCA based indicator for evaluation of alternative energy routes. Appl. Energ. 88(3):630-635.

Rousset P, Pires AC, Sablowski C, Rodrigues T (2011). LCA of eucalyptus wood charcoal briquettes. J. Cle. Pro. 19(14):1647-1653.

Roy P, Nei D, Orikasa T, Xu Q, Okadome H, Nakamura N, Shiina T (2009). A review of life cycle assessment (LCA) on some food products. J. Food Eng. 90(1):1-10.

Sánchez A, Lago A, Xavier F, Ribera J (2011). Innovation Management Practices, Strategic Adaptation, and Business Results: Evidence from the Electronics Industry. J. Technol. Manage. Innov. 6(2):14-39.

Sherwani AF, Usmanib JA, Varun C (2010). Life cycle assessment of solar PV based electricity generation systems: A review. Renew Sust. Energ. Ver. 14(1):540-544.

Tidd J, Bessant JR, Pavitt K (2008). Gestão da inovação. 3rd ed. Porto Alegre: Bookman.

Tseng ML (2010). Using linguistic preferences and grey relational analysis to evaluate the environmental knowledge management capacities. Expert. Syst. Appl. 37(1):70-81.

WIPO (2013). Word Intellectual Property Organization. http://www.wipo.int/portal/index.html.en. [Accessed March 11, 2013]

Wonglimpiyarat $J$ (2005). Does complexity affect the speed of innovation? Technovation 25(8):865-882.

Yung WKC, Chan HK, So JHT, Wong DWC, Choi ACK, Yue TM (2011). A life cycle assessment for eco-redesign of a consumer electronic product: a case study. J. Eng. Des. 22(2):69-85.

Zhou J, Chang VWC, Fane AG (2011). Environmental life cycle assessment of reverse osmosis desalination: The influence of different lifecycle impact assessment methods on the characterization results. Desalination 283(1):227-236. 